\title{
Presynaptic Control of Subunit Composition of NMDA Receptors Mediating Synaptic Plasticity
}

\author{
Kurt Gottmann, Alexander Mehrle, Günter Gisselmann, and Hanns Hatt \\ Lehrstuhl für Zellphysiologie, Ruhr-Universität Bochum, 44780 Bochum, Germany
}

Subunit composition of subsynaptic transmitter receptors is controlled presynaptically in the developing neuromuscular junction. To investigate presynaptic regulation of NMDA receptor subunit composition in the CNS, we co-cultured different types of hippocampal explants with dissociated target neurons. Postsynaptic NMDA receptors were studied using whole-cell patch-clamp recordings.

After 1 week in culture with innervation by dentate gyrus (dg) explants, the kinetic and pharmacological properties of postsynaptic NMDA receptors indicated the expression of NMDA receptor subtypes containing NR2B subunits (NR1/ NR2A/NR2B or NR1/NR2B or both). The properties of NMDA receptors in noninnervated neurons were similar to those of neurons innervated by dg explants. In contrast, after innervation by explants from the cornu ammonis (CA) region, we found an additional NMDA receptor subtype with properties consis- tent with the subunit composition NR1/NR2A. These findings indicate that presynaptic signals determine NMDA receptor subunit composition.

After prolonged cultivation (11-12 d) the properties of synaptic NMDA receptors in the majority of dg-innervated neurons also indicated the expression of NR1/NR2A receptors. This suggests a delayed developmental maturation of NMDA receptors in dg-innervated neurons.

Long-term plasticity of central glutamatergic synapses is critically influenced by the subunit composition of NMDA receptors, and thus presynaptic control of NMDA receptor subunit composition might regulate synaptic plasticity.

Key words: hippocampal cells; developmental maturation; NMDA receptors; synaptic transmission; patch clamp; singlecell $R T-P C R$
In central glutamatergic synapses, NMDA receptors mediate several types of long-term synaptic plasticity (Collingridge and Singer, 1990; Bliss and Collingridge, 1993). NMDA receptor properties crucial for the induction of long-term plasticity are calcium permeability, voltage-dependent $\mathrm{Mg}^{2+}$ block, and slow channel kinetics (Mayer et al., 1984; Nowak et al., 1984; MacDermott et al., 1986; Ascher and Nowak, 1988; Hestrin et al., 1990; Lester et al., 1990; Schneggenburger et al., 1993; McBain and Mayer, 1994). Molecular cloning has revealed NR1 and four types of NR2 subunits (Moriyoshi et al., 1991; Kutsuwada et al., 1992; Meguro et al., 1992; Monyer et al., 1992; Hollmann and Heinemann, 1994). In native NMDA receptor channels, these subunits form hetero-oligomeric complexes (Sheng et al., 1994). In heterologous expression systems, NR1 subunits are necessary for the formation of functional NMDA receptors, whereas the addition of NR2 subunits specifically modifies NMDA receptor properties (Kutsuwada et al., 1992; Monyer et al., 1992, 1994). During development, changes in subunit composition (Watanabe et al., 1992; Williams et al., 1993; Monyer et al., 1994; Sheng et al., 1994) and thus in the properties of NMDA receptors (Carmignoto and Vicini, 1992; Hestrin, 1992; Khazipov et al., 1995) seem to regu-

Received Nov. 27, 1996; revised Jan. 21, 1997; accepted Jan. 30, 1997.

This research was supported by the Deutsche Forschungsgemeinschaft. We thank Drs. A. Konnerth, T. Plant, and C. Schirra for demonstrating single-cell RT-PCR; J. Boulter for NR2A and NR2B subunit cDNAs; and B. W. Ache, M. Behbehani, J. Dudel, S. Kleene, V. Leßmann, R. Lindlbauer, E. Neher, S. Pixley, and B. Rörig for comments on this manuscript. We also thank H. Bartel and H. Jung for technical assistance.

Correspondence should be addressed to Dr. Kurt Gottmann, Lehrstuhl für Zellphysiologie, Ruhr-Universität Bochum, Universitätsstrasse 150, 44780 Bochum, Germany.

Copyright (C) 1997 Society for Neuroscience $\quad 0270-6474 / 97 / 172766-09 \$ 05.00 / 0$ late long-term plasticity of glutamatergic synapses (Crair and Malenka, 1995; Izumi and Zorumski, 1995; Sakimura et al., 1995).

At the developing neuromuscular junction, the presynaptic motoneuron initiates subsynaptic accumulation and changes in subunit composition of muscle acetylcholine receptors (Hall and Sanes, 1993). In the CNS, however, synaptogenesis is complex, because each neuron is contacted by multiple types of presynaptic neurons. Centrally, it is unknown whether presynaptic signals regulate subsynaptic expression and subunit composition of postsynaptic NMDA receptors. There is some suggestion in hippocampal CA3 pyramidal neurons that NMDA receptors are differentially distributed according to specific types of synaptic input (Monaghan and Cotman, 1985; Benke et al., 1993; Petralia et al., 1994; Siegel et al., 1994; Weisskopf and Nicoll, 1995); however, investigation involving experimental manipulation of the innervation is required to analyze the role of presynaptic signaling.

To study presynaptic control of NMDA receptor expression, we developed a co-culture system that permitted innervation of postsynaptic hippocampal neurons by different populations of presynaptic neurons. Innervation sources were explants of embryonic rat hippocampus, from either the dentate gyrus (dg) or the hippocampus proper [cornu ammonis (CA) region]. Dissociated target neurons from the CA region were added at low density. Here we compare the kinetic and pharmacological properties of NMDA receptors in target neurons innervated by $\mathrm{dg}$ or CA explants. Our results indicate that the expression of at least one NMDA receptor subtype is controlled by presynaptic signals.

\section{MATERIALS AND METHODS}

Cell culture. Defined regions, i.e., the dg and the CA region, of the immature hippocampus of rat embryos (embryonic day 19-20; Wistar 
rats) were isolated and cut into explants (diameter $0.3-0.8 \mathrm{~mm}$, with CA explants larger than dg explants). These served as sources of presynaptic fibers. Postsynaptic target neurons were obtained by mechanically dissociating the isolated CA region after trypsin treatment. A $200 \mu \mathrm{l}$ drop of culture medium [Eagle's basal medium supplemented with fetal bovine serum (10\%), insulin, glucose, and L-glutamine (Life Technologies, Gaithersburg, MD)] containing 3-5 $\times 10^{4}$ cells was placed in the center of a polyornithine-coated culture dish. After attachment of dissociated cells, 4-6 dg or CA explants were added. Culture conditions were as described (Gottmann et al., 1994; Pfrieger et al., 1994). Because of the addition of cytosine- $\beta$-D-arabinofuranoside hydrochloride $(10 \mu \mathrm{M}$, after $5 \mathrm{~d}$ in vitro), the cultures contained almost no glial cells outside the explants. The origin of postsynaptic target neurons was confirmed by labeling dissociated neurons with DiI before cultivation. Patch-clamp recordings were obtained only from target neurons that were isolated from other dissociated cells, not from local aggregates of dissociated neurons that formed occasionally.

Electrophysiology and data analysis. Whole-cell patch-clamp recordings were obtained at room temperature as described (Gottmann et al., 1994; Pfrieger et al., 1994). Patch pipettes were filled with $100 \mathrm{~mm}$ potassium gluconate, $10 \mathrm{~mm} \mathrm{KCl}, 0.25 \mathrm{~mm} \mathrm{CaCl}$, 10 mM EGTA, 20 mM HEPES, $\mathrm{pH}$ 7.3. The standard extracellular solution contained $130 \mathrm{~mm} \mathrm{NaCl}, 5 \mathrm{mM} \mathrm{KCl}$, $5 \mathrm{mM} \mathrm{CaCl}_{2}, 20 \mathrm{~mm}$ HEPES, $10 \mu \mathrm{M}$ glycine, $\mathrm{pH}$ 7.3. EPSCs were recorded at a holding potential of $-60 \mathrm{mV}$ near the $\mathrm{Cl}^{-}$equilibrium potential. Paired recordings were performed as described (Pfrieger et al., 1992). Autaptic currents were recorded according to Bekkers and Stevens (1991).

AMPA/kainate receptor-mediated miniature EPSCs (AMPA mEPSCs) were recorded in an extracellular solution with elevated potassium (103 mm NaCl, $32 \mathrm{~mm} \mathrm{KCl,} 5 \mathrm{~mm} \mathrm{CaCl}, 1 \mathrm{~mm} \mathrm{MgCl}_{2}, 20 \mathrm{~mm}$ HEPES, pH 7.3) and with $1 \mu \mathrm{M}$ tetrodotoxin (TTX) at a holding potential of $-60 \mathrm{mV}$. Analysis of mEPSC frequencies and amplitudes was performed using AUTESP software (H. Zucker, Max-Planck-Institute for Psychiatry, Martinsried, Germany), as described (Gottmann et al., 1994). Local application of high potassium solution $(32 \mathrm{~mm})$ was performed according to Bekkers and Stevens (1989). At a holding potential of $-10 \mathrm{mV}$, GABAergic mIPSCs occurred in all cells tested $(n=6)$. mIPSCs were blocked after the addition of bicuculline methochloride $(20 \mu \mathrm{M} ; n=4)$.

To record NMDA receptor-mediated EPSCs (NMDA EPSCs), the extracellular solution contained $130 \mathrm{~mm} \mathrm{NaCl}, 5 \mathrm{mM} \mathrm{KCl}, 5 \mathrm{mM} \mathrm{CaCl}_{2}, 20$ mM HEPES, pH 7.3, $10 \mu \mathrm{M}$ glycine, $10 \mu \mathrm{M}$ 6,7-dinitroquinoxaline-2,3dione (DNQX), $20 \mu \mathrm{M}$ bicuculline methochloride. The holding potential was $-60 \mathrm{mV}$. NMDA EPSCs were evoked by extracellular stimulation of explant fibers by means of a patch pipette (tip diameter 5-10 $\mu \mathrm{m}$ ) filled with extracellular solution using $200 \mu \mathrm{sec}-1 \mathrm{msec}$ pulses of $50-80 \mathrm{~V}$. The decay of evoked NMDA EPSCs was fitted after 10 individual synaptic responses were averaged using PCLAMP 6.0 software (Axon Instruments, Foster City, CA). For pharmacological characterization of NMDA EPSC bursts, postsynaptic target cells were selectively superfused as described (Pfrieger et al., 1994), without applying the antagonists to the explants. Evoked AMPA/kainate receptor-mediated EPSCs were recorded in extracellular solution after omission of DNQX and addition of $1 \mathrm{mM} \mathrm{MgCl}$.

mEPSCs were recorded at a holding potential of $-60 \mathrm{mV}$ in the presence of $1 \mu \mathrm{M}$ TTX in the extracellular solution. The extracellular $\mathrm{Ca}^{2+}$ concentration was reduced to $3 \mathrm{mM}$, and DNQX was omitted from the extracellular solution to facilitate the detection of small-amplitude NMDA receptormediated components by means of the AMPA/kainate receptor-mediated component. To determine the decay kinetics of NMDA receptor-mediated components, mEPSCs were aligned and averaged (Bekkers and Stevens, 1989) by means of AUTESP software using the AMPA/kainate receptormediated component as a detection signal. For each cell, 25-100 mEPSCs showing an NMDA receptor-mediated component were averaged. The decay of the averaged NMDA receptor-mediated component was fitted using PCLAMP 6.0 software. NMDA receptor-mediated components were selectively blocked by $50 \mu \mathrm{M}$ D-AP-5.

Fast L-glutamate application. Fast application and removal of L-glutamate $(100 \mu \mathrm{M})$ was achieved by means of a pressure-driven, two-barrel application system combined with a continuously operating suction barrel. This perfusion system removes the agonist from whole hippocampal neurons within $20-30 \mathrm{msec}$, as shown by recording the unblocking kinetics of voltage-dependent $\mathrm{Ca}^{2+}$ currents after removal of $\mathrm{Cd}^{2+}$ (Pfrieger et al., 1994). Open pipette responses occurred within 1 msec. To isolate NMDA receptor-mediated currents, the extracellular solution consisted of $130 \mathrm{~mm} \mathrm{NaCl}, 5 \mathrm{mM} \mathrm{KCl}, 2 \mathrm{mM} \mathrm{CaCl}_{2}, 20 \mathrm{~mm}$ HEPES, pH 7.3, $10 \mu \mathrm{M}$ glycine, $10 \mu \mathrm{M}$ DNQX. The holding potential was
$-60 \mathrm{mV}$. L-Glutamate was applied for 100 or $300 \mathrm{msec}$ by switching from the barrel containing control solution to the barrel containing agonist using electrically operated valves. Fast removal of L-glutamate was performed by switching back to the barrel containing control solution. For local dendritic application of L-glutamate, a $30 \mu \mathrm{m}$ tip diameter glass pipette was used to apply agonist. Local application resulted in a mean reduction of the peak current amplitude by $70 \pm 11 \%(n=15)$ compared with the whole-cell current and was confirmed by the addition of dye. Fast application of $\mathrm{Mg}^{2+}$ was performed after activation of NMDA receptormediated currents by switching from the barrel containing L-glutamate to a barrel containing L-glutamate $(100 \mu \mathrm{M})$ and $\mathrm{Mg}^{2+}(1 \mathrm{mM})$. The amount of $\mathrm{Mg}^{2+}$ block was determined by comparing current amplitudes before and $100 \mathrm{msec}$ after the onset of $\mathrm{Mg}^{2+}$ application. Offset kinetics of NMDA receptor-mediated currents and kinetics of $\mathrm{Mg}^{2+}$ block were determined by fitting the current decay after five trials were averaged. Increasing the extracellular $\mathrm{Ca}^{2+}$ concentration to $5 \mathrm{~mm}$ did not alter offset kinetics $(n=2)$.

Single-cell reverse transcription (RT)-PCR. Cellular RNA harvest, firststrand reaction, and PCR amplification were performed according to Lambolez et al. (1992). The pipette solution (100 mM KCl, $3 \mathrm{~mm} \mathrm{MgCl}_{2}$, 5 mM EGTA, $10 \mathrm{~mm}$ HEPES, pH 7.4) containing cellular mRNA and random hexamers $(6 \mathrm{pmol} / \mu \mathrm{l})$ was expelled into a reaction tube containing DTT and desoxyribonucleotides (final concentration $10 \mathrm{~mm}$ and 500 $\mu \mathrm{M}$, respectively). Fifteen units of RNAsin (Promega, Madison, WI) and $100 \mathrm{U}$ of Moloney Murine Leukemia Virus (M-MLV) reverse transcriptase (Life Technologies) were added per $10 \mu \mathrm{l}$, and the first-strand mix was incubated at $37^{\circ} \mathrm{C}$ for $60-90 \mathrm{~min}, 80^{\circ} \mathrm{C}$ for $10 \mathrm{~min}$. To PCRamplify a specific fragment from the rat NMDA receptor subunits NR2A and NR2B (Monyer et al., 1992), two oligonucleotide primers were designed: upper primer $=$ CTGGCCT $(\mathrm{G}, \mathrm{C})$ AGTGACAAGAAGTTCC, corresponding to positions $1988-2011$ on NR2A and 1991-2014 on NR2B; lower primer $=$ CAGATGAAGGTGATGAGGCTGAGG, corresponding to positions $2487-2510$ on NR2A and $2490-2513$ on NR2B (position 1 is the first base of the initiation codon). Amplification reactions were performed with $20 \mathrm{~mm}$ Tris- $\mathrm{HCl}, \mathrm{pH} 8.4,50 \mathrm{~mm} \mathrm{KCl}, 1.5 \mathrm{~mm}$ $\mathrm{MgCl}_{2}, 50 \mathrm{~mm}$ of each desoxyribonucleotide (final concentration), 20 pmol of upper and lower primer, and $10 \mu \mathrm{l}$ of first-strand mix in $100 \mu \mathrm{l}$, with the following temperature protocol: $96^{\circ} \mathrm{C}$ for $4 \mathrm{~min}, 80^{\circ} \mathrm{C}$ to add 2.5 $\mathrm{U}$ of taq DNA-polymerase (Life Technologies), 40 cycles $\left(94^{\circ} \mathrm{C}\right.$ for $30 \mathrm{sec}$, $68^{\circ} \mathrm{C}$ for $1 \mathrm{~min}, 72^{\circ} \mathrm{C}$ for $\left.1 \mathrm{~min}\right), 72^{\circ} \mathrm{C}$ for $10 \mathrm{~min}$. The PCR product was reamplified (same PCR conditions but only 30 cycles) and after purification was subjected to a restriction enzyme digestion (HinfI, Promega); $50-100 \mathrm{ng}$ of the digested fragments was resolved on a $2 \%$ agarose gel and blotted onto a nylon membrane (Hybond $\mathrm{N}^{+}$, Amersham, Arlington Heights, IL). For hybridization, digoxygenin-labeled, PCR-generated fragments specific for the subunits NR2A and NR2B were used. Hybridization (high stringency conditions), washes, and detection (NBT/Xphosphate color reaction) were performed according to the Dig Systems Users Guide for Filter Hybridization (Boehringer Mannheim, Indianapolis, IN). No NR2A or NR2B amplification products were obtained with mRNA harvested from single non-neuronal cells, thus demonstrating the lack of contamination.

\section{RESULTS}

\section{Formation of glutamatergic synapses between presynaptic explants and postsynaptic target neurons}

After 7-9 d in vitro, target neurons were strongly innervated by explant fibers (Fig. 1A). Both types of explant fibers established glutamatergic synapses on target neurons, as indicated by bursts of EPSCs that were elicited in target neurons after extracellular electrical stimulation of explants and by spontaneous EPSCs (sEPSCs) (Fig. 1B). To confirm that the sEPSCs were attributable to synaptic input arising from the explants, we tested whether target neurons innervate each other by means of paired recordings. Out of 20 possible synaptic connections tested (dginnervated, $n=5$ pairs; CA-innervated, $n=5$ pairs), only one small amplitude synapse $(<100 \mathrm{pA})$ was detectable. Innervated target neurons $(n=15)$ did not exhibit autaptic currents. To study whether explant fibers form synapses on the majority of target neurons or selectively on a subset of target neurons, we recorded sEPSCs from more than 10 target neurons surrounding the same 
A

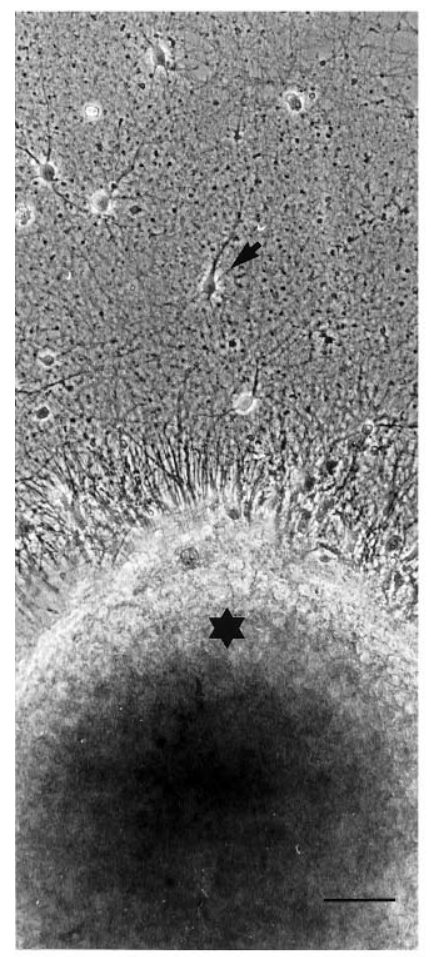

B
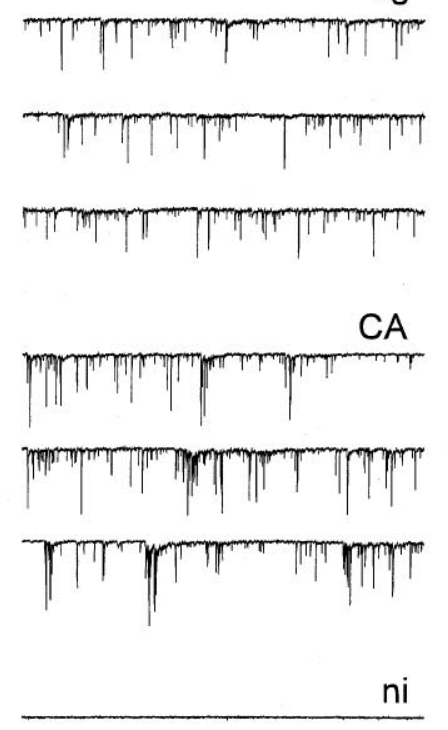

ni

$1 \mathrm{~s}$

C

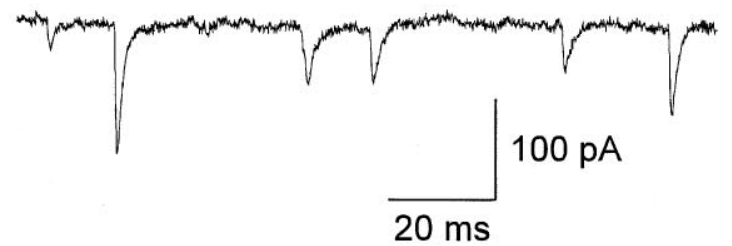

D

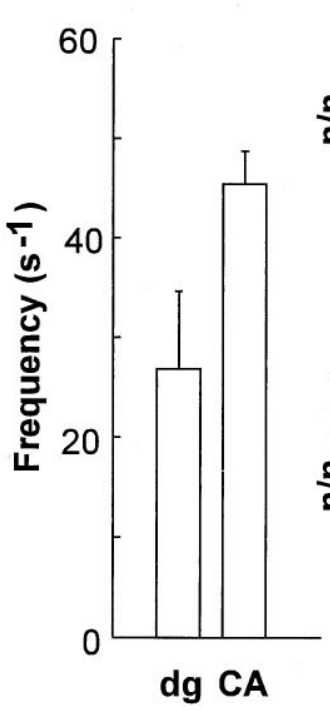

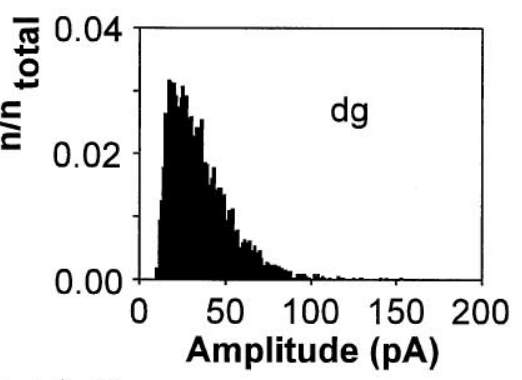

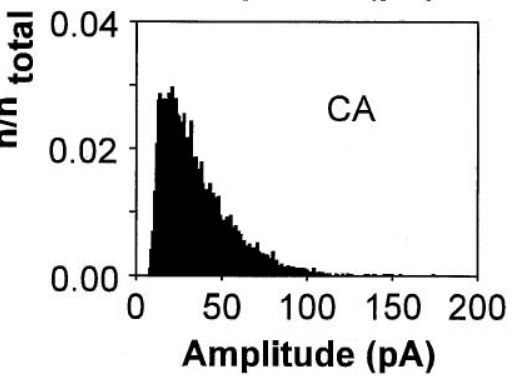

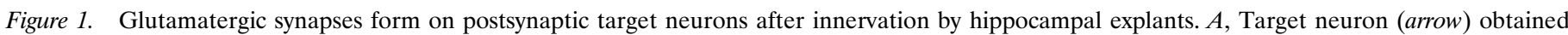

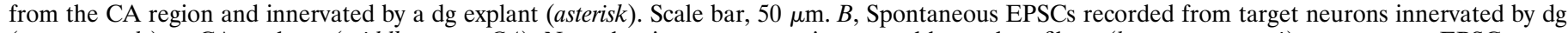

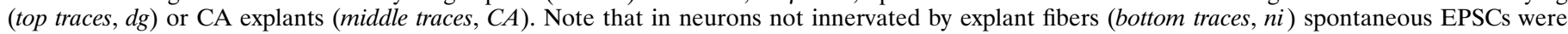

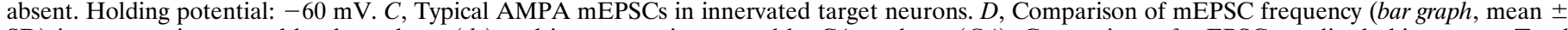

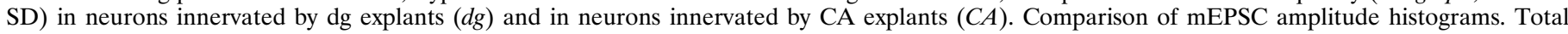

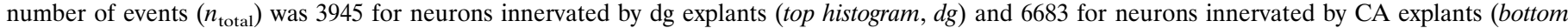
histogram, $C A)$.

explant. Spontaneous EPSCs occurred at a frequency of at least $0.5 \mathrm{sec}^{-1}$ in $82 \%$ of dg-innervated neurons ( $n=34,3$ explants) and in $89 \%$ of CA-innervated neurons ( $n=35,3$ explants). Spontaneous EPSCs were absent in noninnervated neurons located outside the area covered by explant fibers (Fig. $1 B$ ). In the vast majority ( 10 of 13 cells tested) of neurons not innervated by explant fibers, autaptic currents were also absent. Only in three neurons were small amplitude $(<50 \mathrm{pA})$ autaptic currents detectable.

To compare innervation by dg and CA explants, we recorded AMPA/kainate receptor-mediated mEPSCs (AMPA mEPSCs) in high potassium $(32 \mathrm{~mm})$ extracellular solution containing $1 \mathrm{~mm}$ $\mathrm{Mg}^{2+}$. AMPA mEPSCs were blocked by the addition of DNQX (10 $\mu \mathrm{M} ; n=5)$. Amplitudes of AMPA mEPSCs (Fig. 1C) in neurons innervated by $\mathrm{dg}$ explants were comparable to those in neurons innervated by CA explants (Fig. 1D). AMPA mEPSC frequencies were slightly lower in dg-innervated neurons (dginnervated: $26.8 \pm 7.8 \mathrm{sec}^{-1}, n=3$; CA-innervated: $45.4 \pm 3.3$ $\sec ^{-1}, n=3$ ) (Fig. 1D). To exclude selective innervation of specific regions of target neurons, we elicited AMPA EPSCs by local application of high potassium solution to proximal and distal dendritic regions. In all target neurons examined (dg-innervated, $n=4$; CA-innervated, $n=4$ ), AMPA EPSCs were elicited in both proximal and distal dendritic regions.

\section{Decay kinetics and pharmacological properties of NMDA EPSCs depend on the type of innervation}

To study the properties of NMDA EPSCs, DNQX (10 $\mu \mathrm{M})$ was added to block AMPA/kainate receptors and bicuculline methochloride $(20 \mu \mathrm{M})$ to block $\mathrm{GABA}_{\mathrm{A}}$ receptors (in nominally $\mathrm{Mg}^{2+}$. free solution containing $10 \mu \mathrm{M}$ glycine). In the presence of bicuculline methochloride, NMDA receptor-mediated postsynaptic currents occurred spontaneously in innervated neurons, with a mean frequency of $0.05 \pm 0.03 \mathrm{sec}^{-1}$. They were dependent on action potential activity in the explant fibers, because they were blocked by the addition of $1 \mu \mathrm{M}$ TTX $(n=5)$, were absent after explant removal without damaging the outgrown fibers and postsynaptic target neurons by means of a fine-tip pipette under visual control $(n=7)$, and were absent in noninnervated neurons $(n=6)$. As indicated by their slow rise times (mean time-to-peak: $129 \pm 47 \mathrm{msec}$ ), they were elicited by asynchronous transmitter release caused by rhythmic action potential activity and thus represent spontaneous bursts of NMDA EPSCs. Interestingly, the decay kinetics of spontaneous NMDA EPSC bursts depended strikingly on the type of innervation (Fig. 2). In 23 of 25 neurons innervated by CA explants, the decay of NMDA EPSC bursts could be fit by the weighted sum of two exponentials. Mean time constants were $131 \pm 36$ (SD) and $1039 \pm 379 \mathrm{msec}$, with the fast 
A

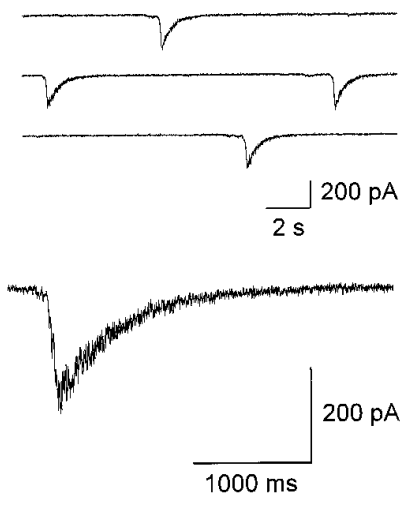

B
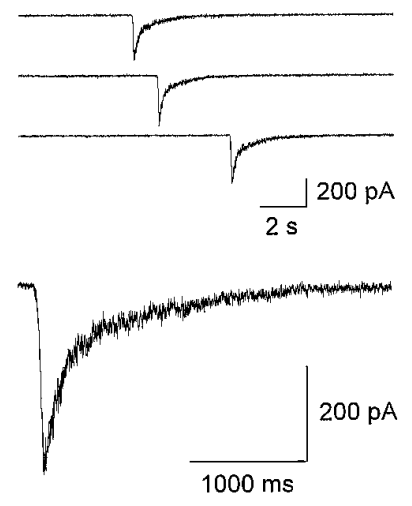

Figure 2. After 1 week in culture, decay kinetics of NMDA EPSC bursts depend on the type of innervation. $A, B$, Successive spontaneous NMDA EPSC bursts recorded from target neurons innervated by $\operatorname{dg}(A)$ and CA $(B)$ explants (top traces). Holding potential: $-60 \mathrm{mV}$. Bottom traces show spontaneous NMDA EPSC bursts on an expanded time scale. NMDA EPSC bursts of comparable amplitudes are shown.

component contributing $>50 \%$ to the total amplitude. In contrast, in the vast majority ( 21 of 27 cells) of neurons innervated by $\mathrm{dg}$ explants, NMDA EPSC bursts showed monoexponential decay kinetics with a mean time constant of $620 \pm 268 \mathrm{msec}$. In the remaining six neurons, a small $(<50 \%$ of total amplitude), fast decaying component $(162 \pm 21 \mathrm{msec})$ was detectable in approximately one third of the EPSCs. The amplitudes of spontaneous NMDA EPSC bursts differed significantly $(p<0.001)$ between neurons innervated by $\mathrm{dg}$ and CA explants, with mean values of $111 \pm 59$ and $745 \pm 360 \mathrm{pA}$, respectively.

To demonstrate innervation-dependent differences in NMDA EPSC decay kinetics, we elicited NMDA EPSCs by extracellular stimulation of explant fibers. Evoked NMDA EPSCs showed much shorter rise times (mean time-to-peak: $22 \pm 9 \mathrm{msec}$ ) compared with spontaneous NMDA EPSC bursts attributable to more synchronous transmitter release. The decay kinetics of evoked NMDA EPSCs showed a strong dependence on the type of presynaptic explant (Fig. $3 A, B$ ). In all neurons innervated by CA explants $(n=7)$, the decay of evoked NMDA EPSCs could be fit by the sum of two exponentials with mean time constants of $71 \pm$ $13 \mathrm{msec}(60-80 \%$ of the total amplitude) and $489 \pm 98 \mathrm{msec}$. In contrast, in five of seven neurons innervated by $\mathrm{dg}$ explants, evoked NMDA EPSCs showed monoexponential decay kinetics with a mean time constant of $416 \pm 161 \mathrm{msec}$. An additional fast decaying component $(\tau<100 \mathrm{msec})$ was detectable in the remaining two neurons. Mean amplitudes were significantly smaller ( $p<$ $0.001)$ in dg-innervated neurons $(42 \pm 31 \mathrm{pA})$ compared with CA-innervated neurons $(214 \pm 73 \mathrm{pA})$. To assess the kinetic properties of synaptic NMDA receptors under conditions of minimal transmitter release, we recorded mEPSCs in the presence of $1 \mu \mathrm{M}$ TTX. DNQX was omitted from the extracellular solution, and the AMPA/kainate receptor-mediated component was used for detection of mEPSCs. Similar to evoked NMDA EPSCs, the decay kinetics of the NMDA receptor-mediated component of mEPSCs were strongly dependent on the type of presynaptic explant (Fig. 3C-E). In six of seven neurons innervated by CA explants, the decay of the NMDA receptor-mediated component could be fit by the sum of two exponentials with mean time constants of $61 \pm 25 \mathrm{msec}(60-90 \%$ of the total amplitude) and $379 \pm 120 \mathrm{msec}$. In six of eight neurons innervated by dg explants,

the decay of the NMDA receptor-mediated component showed monoexponential kinetics with a mean time constant of $170 \pm 51$ msec. In the remaining two neurons, a fast decaying component $(\tau$ $<100 \mathrm{msec}$ ) was detectable.

Channel kinetics of NMDA receptors determine decay kinetics of NMDA EPSCs (Hestrin et al., 1990; Lester et al., 1990), and channel kinetics are in turn determined by subunit composition. In heterologous expression systems, binary NR1/NR2A receptors are characterized by fast $(\tau \sim 100 \mathrm{msec})$ offset kinetics, whereas NR1/NR2B receptors show slow $(\tau \sim 400 \mathrm{msec})$ offset kinetics (Monyer et al., 1994). Offset kinetics of ternary NR1/NR2A/ NR2B receptors are intermediate $(\tau \sim 200 \mathrm{msec}$ ) (Köhr and Seeburg, 1996). Thus the observed innervation-dependent differences in decay kinetics indicate that the subsynaptic expression of an additional NMDA receptor subtype was presynaptically induced by CA explants. The additional NMDA receptor subtype with fast offset kinetics most likely consisted of NR1 and NR2A subunits.

To confirm innervation-dependent differences in subunit composition, we characterized synaptic NMDA receptors using subunit selective antagonists. We studied spontaneous NMDA EPSC bursts, because their amplitudes were much larger compared with those of evoked or miniature NMDA EPSCs. Postsynaptic neurons were locally superfused, whereas the explants remained in antagonist-free solution. D-AP-5 $(50 \mu \mathrm{M})$ reversibly blocked NMDA EPSC bursts by $>80 \%$ in neurons innervated by $\mathrm{dg}$ explants $(n=3)$ as well as in neurons innervated by CA explants $(n=3)$.

In heterologous expression systems, NMDA receptor subtypes containing NR2A or NR2B subunits are more sensitive to $\mathrm{Mg}^{2+}$ blockade than are NMDA receptor subtypes containing NR2C or NR2D subunits (Kutsuwada et al., 1992; Monyer et al., 1992, 1994). At a holding potential of $-60 \mathrm{mV}, 1 \mathrm{mM} \mathrm{Mg}^{2+}$ reversibly reduced the peak amplitudes of NMDA EPSC bursts by $90 \pm 9 \%$ (dg-innervated, $n=5$ ) and $86 \pm 2 \%$ (CA-innervated, $n=5$ ) without significant differences (Fig. $4 A, B$ ). A low concentration of $\mathrm{Mg}^{2+}(0.1 \mathrm{mM})$ also strongly reduced NMDA EPSC amplitudes in neurons innervated by $\mathrm{dg}(65 \pm 13 \%, n=3)$ and CA $(60 \pm 6 \%$, $n=3)$ explants. These results indicate that NMDA EPSCs were largely mediated by NMDA receptor subtypes containing NR2A or NR2B subunits.

NMDA receptor subtypes containing NR2B subunits are selectively blocked by ifenprodil, whereas the receptor subtypes NR1/ NR2A, NR1/NR2C, or NR1/NR2D are much less sensitive (Williams et al., 1993; Williams, 1995). Ifenprodil (3 $\mu \mathrm{M})$ reversibly blocked peak amplitudes of NMDA EPSC bursts in neurons innervated by dg explants by $79 \pm 3 \%(n=7)$. In contrast, NMDA EPSC bursts in neurons innervated by CA explants were reduced in amplitude only by $48 \pm 8 \%(n=7)$ (Fig. $4 C, D)$. This innervation-dependent difference in sensitivity to ifenprodil was statistically significant $(p<0.001)$. Ifenprodil $(3 \mu \mathrm{M})$ did not significantly affect evoked AMPA EPSCs recorded in the presence of $1 \mathrm{mM} \mathrm{Mg}^{2+}$ (dg-innervated, $n=3$; CA-innervated, $n=3$ ). In line with our results, a significant $(>10 \%)$ block of voltagedependent calcium channels was observed only at ifenprodil concentrations higher than $3 \mu \mathrm{M}$ in cultured hippocampal neurons (Church et al., 1994). This excludes the possibility that the differences in sensitivity to ifenprodil were attributable to differential presynaptic inhibition of transmitter release by ifenprodil. Thus, a NMDA receptor subtype containing NR2B subunits (NR1/ NR2A/NR2B or NR1/NR2B or both) mediated NMDA EPSCs in neurons innervated by $\mathrm{dg}$ explants. Obviously, an additional 
A

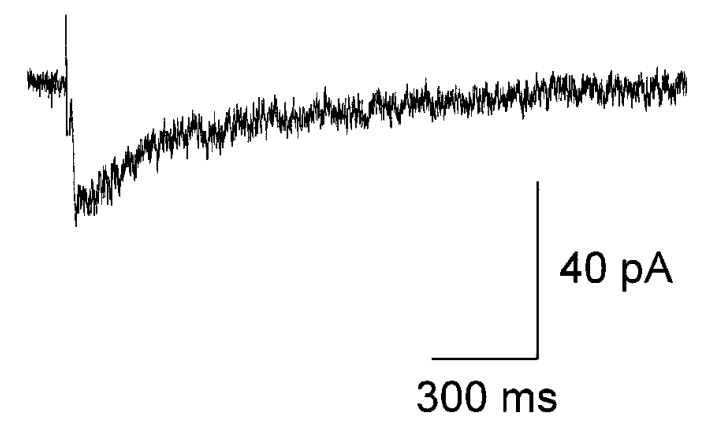

C
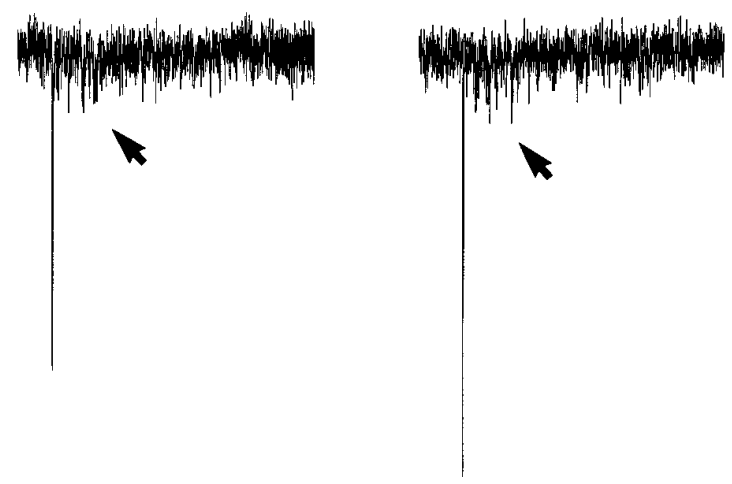

B
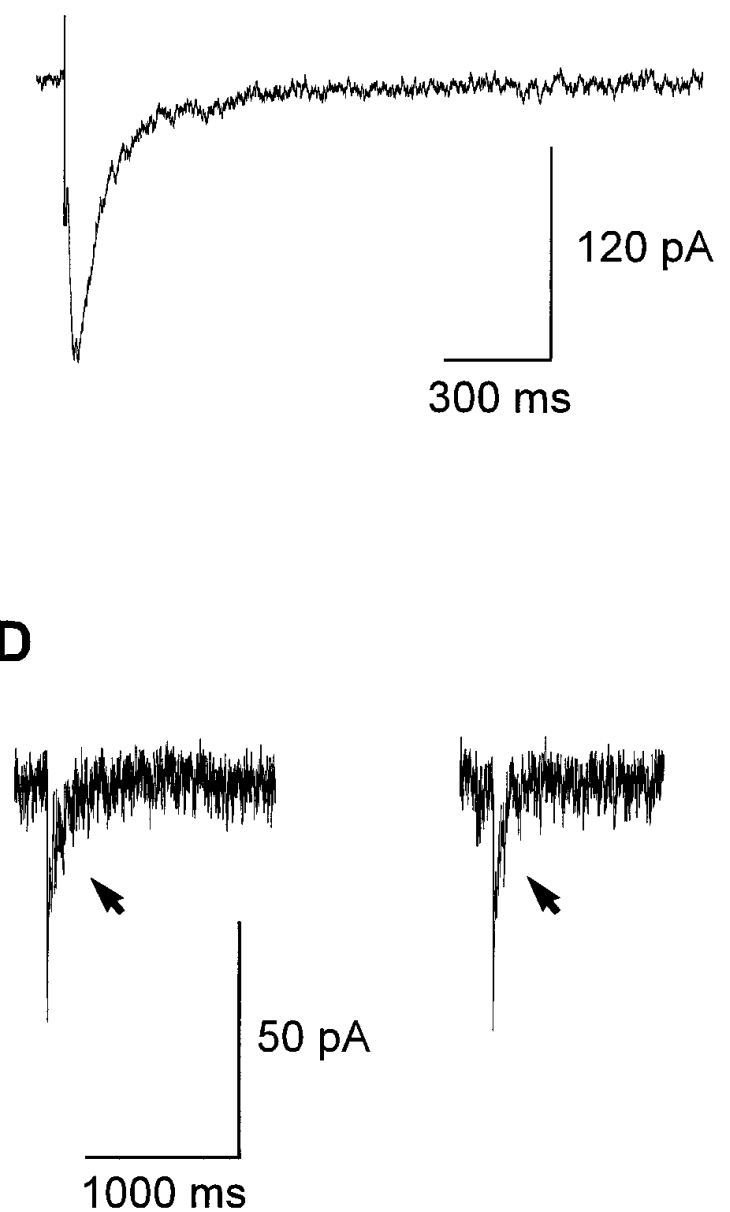

$\mathbf{E}$

AP-5

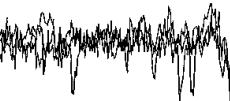

dg

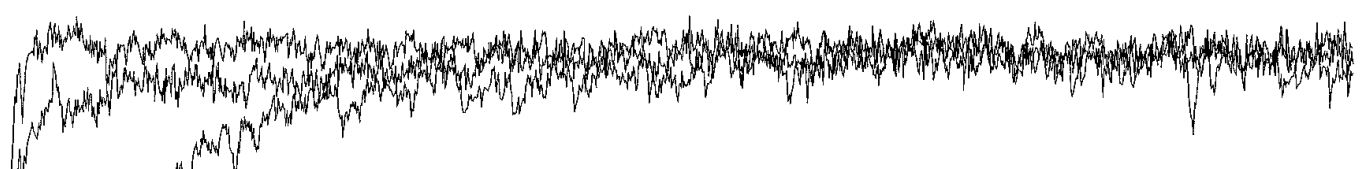

Figure 3. After 7-9 d in culture, decay kinetics of NMDA EPSCs depend on the type of innervation. $A$, $B$, Averages of 10 NMDA EPSCs evoked by extracellular stimulation in target neurons innervated by $\operatorname{dg}(A)$ and CA $(B)$ explants. Stimulus artifacts are truncated. Holding potential: $-60 \mathrm{mV}$. Note the innervation-dependent differences in decay kinetics. $C-E$, NMDA receptor-mediated components of mEPSCs. $C$, $D$, Individual mEPSCs recorded in a dg-innervated neuron $(C)$ and in a CA-innervated neuron $(D)$. Holding potential: $-60 \mathrm{mV}$. NMDA receptor-mediated components after the AMPA/kainate receptor-mediated component are indicated by arrows. E, NMDA receptor-mediated components of average mEPSCs recorded in a dg-innervated neuron $(d g)$ and in a CA-innervated neuron $(C A)$. The AMPA/kainate receptor-mediated component is truncated. D-AP-5 (50 $\mu \mathrm{M})$ selectively blocked the NMDA receptor-mediated components $(A P-5)$. 
A
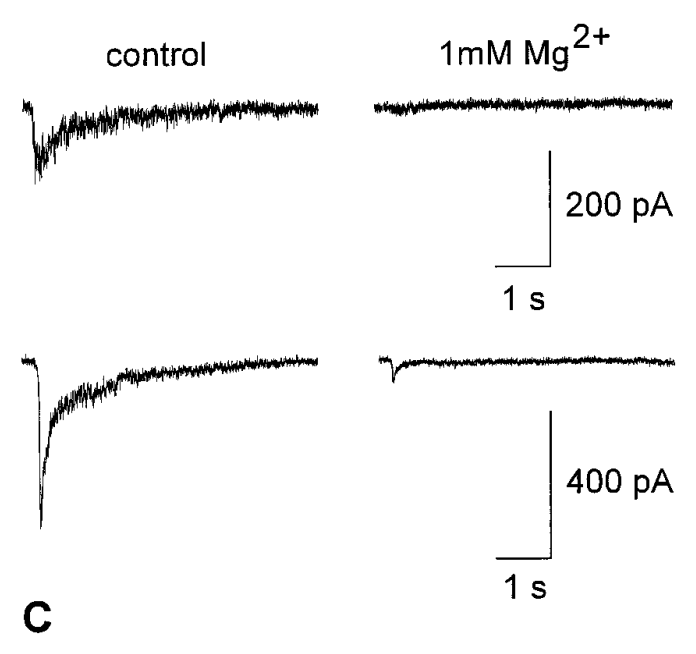

control
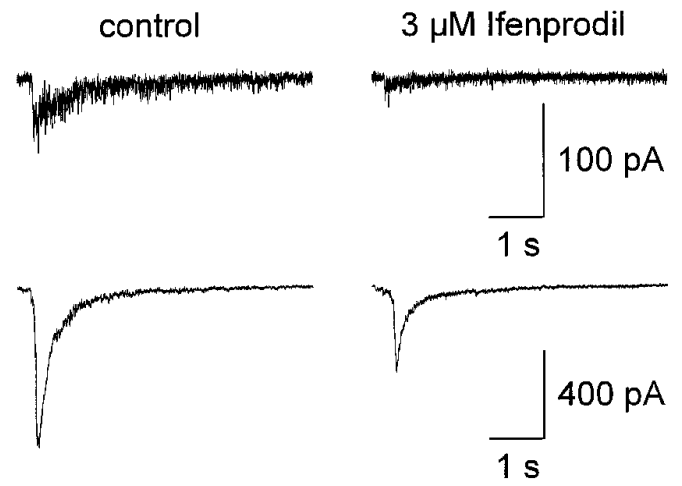

B
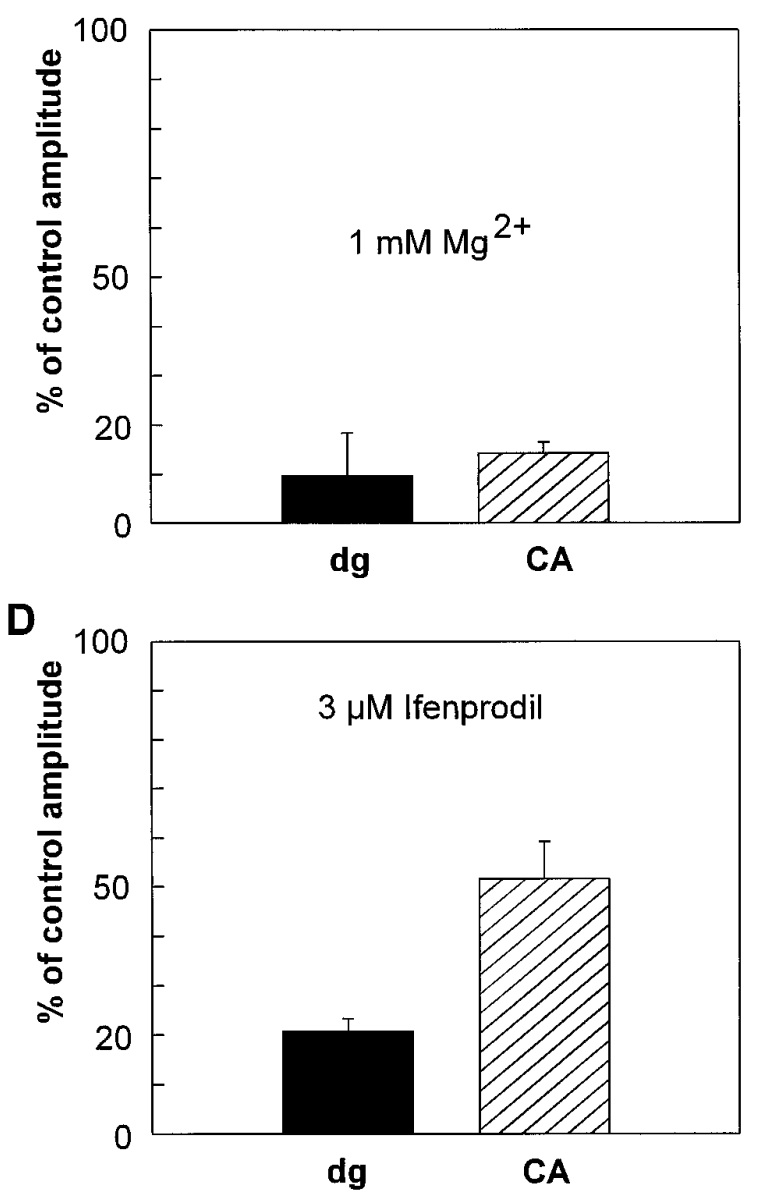

Figure 4. Pharmacological properties of NMDA EPSC bursts depend on the type of innervation after 1 week in culture. $A$, Reversible blockade of spontaneous NMDA EPSC bursts in neurons innervated by dg explants (top traces, $d g$ ) and in neurons innervated by CA explants (bottom traces, $C A$ ) by addition of $1 \mathrm{~mm} \mathrm{Mg}^{2+}$. Holding potential: $-60 \mathrm{mV}$. B. Plot of NMDA EPSC burst peak amplitudes in the presence of $1 \mathrm{mM} \mathrm{Mg}^{2+}$ normalized to peak amplitudes under control conditions (mean $\pm \mathrm{SD})$ for neurons innervated by dg explants $(d g, 10 \pm 9 \%)$ and CA explants $(C A, 14 \pm 2 \%)$. $C$, Reversible effects of the NR2B subunit-selective blocker ifenprodil $(3 \mu \mathrm{M})$ on spontaneous NMDA EPSC bursts in neurons innervated by dg explants (top traces, $d g$ ) and in neurons innervated by CA explants (bottom traces, $C A$ ). Holding potential: $-60 \mathrm{mV}$. $D$, Plot of NMDA EPSC burst peak amplitudes in the presence of $3 \mu \mathrm{M}$ ifenprodil normalized to peak amplitudes under control conditions (mean $\pm \mathrm{SD}$ ) for neurons innervated by dg explants $(d g, 21 \pm 3 \%)$ and CA explants $(C A, 52 \pm 8 \%)$. Note the innervation-dependent difference in sensitivity to ifenprodil.

NMDA receptor subtype contributed to NMDA EPSCs in neurons innervated by CA explants. As indicated by the fast decay kinetics of NMDA EPSCs, the NR1/NR2A receptor subtype was additionally present.

\section{Offset kinetics of NMDA receptor-mediated currents depend on the type of innervation}

Depending on subunit composition, NMDA receptor subtypes show characteristic offset kinetics of NMDA receptor-mediated currents (Monyer et al., 1992, 1994; Köhr and Seeburg, 1996). To examine whether NMDA receptors of the NR1/NR2A subtype are selectively expressed by neurons innervated by $\mathrm{CA}$ explants, we studied offset kinetics of NMDA receptors. We evoked NMDA receptor-mediated currents by fast application of L-glutamate $(100 \mu \mathrm{M})$ in the presence of DNQX $(10 \mu \mathrm{M})$ to block AMPA/kainate receptors. Mean peak amplitudes of NMDA receptor-mediated whole-cell currents were $2.57 \pm 1.39 \mathrm{nA}$ (dginnervated), $2.25 \pm 0.90 \mathrm{nA}$ (CA-innervated), and $1.33 \pm 0.65 \mathrm{nA}$ (noninnervated neurons). NMDA receptor-mediated currents were reversibly blocked by $>80 \%$ in the presence of $100 \mu \mathrm{M}$
DL-AP-5 (dg-innervated, $n=5$; CA-innervated, $n=5$ ). The addition of $1 \mathrm{~mm} \mathrm{Mg}^{2+}$ reversibly blocked NMDA receptormediated currents at a holding potential of $-60 \mathrm{mV}$ by $88 \pm 4 \%$ in neurons innervated by dg explants $(n=7)$ and by $83 \pm 6 \%$ in neurons innervated by CA explants $(n=7)$. The $\mathrm{Mg}^{2+}$ block developed with a mean time constant of $13 \pm 5 \mathrm{msec}$ (Fig. $5 A$ ). Thus, superfusion of the whole neuron was sufficiently fast to resolve differences in the offset kinetics of NMDA receptor subtypes.

Offset kinetics of NMDA receptor-mediated currents could be fit by the weighted sum of two exponentials. In neurons innervated by $\mathrm{dg}$ explants $(n=11)$, offset kinetics of NMDA receptormediated currents elicited by dendritic application of L-glutamate showed a mean fast time constant of $218 \pm 38 \mathrm{msec}$. In contrast, neurons innervated by CA explants $(n=10)$ showed a mean value of $126 \pm 25 \mathrm{msec}$ (Fig. $5 B$ ). This difference was statistically significant $(p<0.001)$. Whole-cell NMDA receptor-mediated currents exhibited a similar innervation-dependent difference in offset kinetics (dg-innervated: $210 \pm 37 \mathrm{msec}, n=16$; CA- 
A

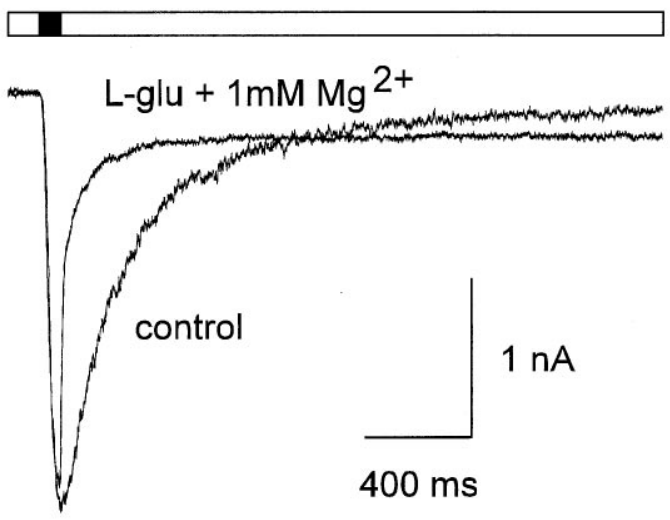

C
B

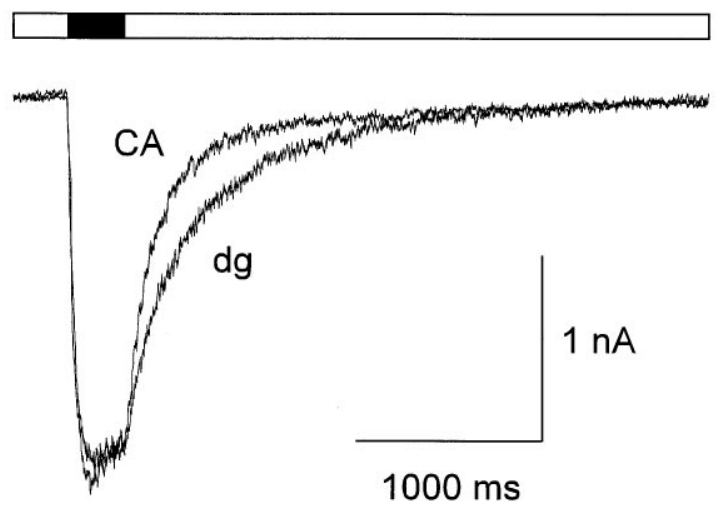

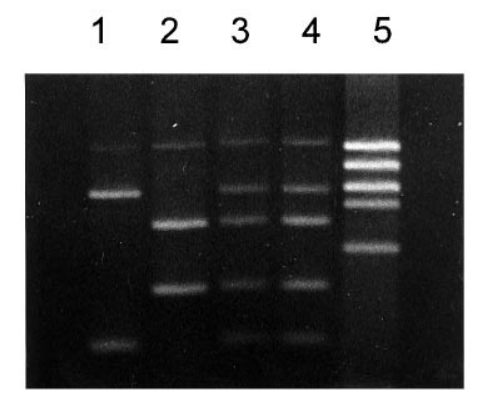
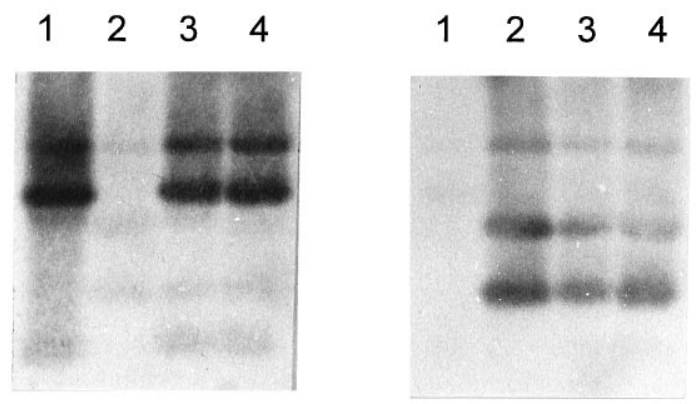

Figure 5. Innervation dependence of functional expression of NMDA receptor subtypes after 7-9 d in culture. $A$, Control: NMDA receptor-mediated whole-cell current evoked by application of $100 \mu \mathrm{M}$ L-glutamate. Black bar indicates L-glutamate application (100 msec). $L_{\text {-glu }}+1 \mathrm{mM} \mathrm{Mg}^{2+}$ : Blockade of NMDA receptor-mediated whole-cell current by addition of $1 \mathrm{mM} \mathrm{Mg}^{2+}$ in the continued presence of L-glutamate. Holding potential: $-60 \mathrm{mV}$. $B$, NMDA receptor-mediated currents evoked by application of $100 \mu \mathrm{M} \mathrm{L}$-glutamate selectively to dendrites. Black bar indicates L-glutamate application (300 msec). Offset kinetics were faster in neurons innervated by CA explants $(C A)$ compared with neurons innervated by dg explants $(d g)$. $C$, Agarose gel electrophoresis of PCR products after HinfI digestion. Templates used to PCR-amplify 523 bp fragments: Lane 1: plasmid vector containing NR2A cDNA; 2: plasmid vector containing NR2B cDNA; 3: cDNA obtained from a CA-innervated neuron; 4: cDNA obtained from a dg-innervated neuron; 5: molecular weight marker. Fragment sizes in lane 4, from top: $523 \mathrm{bp}$ (undigested PCR products), $390 \mathrm{bp}$ (NR2A), $315 \mathrm{bp}$ (NR2B), $208 \mathrm{bp}$ (NR2B), $133 \mathrm{bp}$ (NR2A). The top band (523 bp) represents PCR products not digested by the restriction enzyme. This band contains NR2A and NR2B fragments and thus hybridizes with both NR2A and NR2B probes. $D$, Southern blot analysis of the gel shown in $C$ at the same scale to confirm identification of fragments. For hybridization, digoxygenin-labeled NR2A (left panel) or NR2B (right panel) specific probes (523 bp) were used. Hybridization with the NR2A specific probe was performed at lower stringency conditions to detect the 133 bp fragment, because hybridization signals were weak because of its small size.

innervated: $157 \pm 48 \mathrm{msec}, n=22 ; p<0.01)$. In neurons not innervated by explant fibers, the fast time constant $(201 \pm 42$ msec, $n=14$ ) was similar to that in neurons innervated by $\mathrm{dg}$ explants. The second, slow time constant in offset kinetics ranged from $500 \mathrm{msec}$ to $2 \mathrm{sec}$ and was not dependent on innervation.

Analysis of NMDA receptor-mediated currents thus revealed fast offset kinetics consistent with the expression of NR1/NR2A receptors in neurons innervated by CA explants. Ternary NMDA receptors of the NR1/NR2A/NR2B subtype are characterized by offset kinetics $(\tau \sim 200 \mathrm{msec})$ intermediate between the fast kinetics of NR1/NR2A receptors and the slow kinetics of NR1/ NR2B receptors. Offset kinetics in dg-innervated and noninnervated neurons were thus consistent with the expression of NR1/ NR2A/NR2B receptors. To examine whether NR2A subunits are expressed in dg-innervated and noninnervated neurons, we analyzed the expression of the NMDA receptor subunits NR2A and NR2B at the mRNA level. We used the single-cell RT-PCR technique to specifically amplify cDNA obtained from individual cells. Subsequent restriction-enzyme analysis, Southern blotting, and hybridization of PCR products revealed NR2A mRNA expression, independent of the type of innervation, in almost all neurons examined (in 8 of 10 neurons innervated by CA explants, in 7 of 10 neurons innervated by dg explants, and in 8 of 10 noninnervated neurons) (Fig. 5C,D). Similarly, NR2B mRNA was detected, regardless of innervation, in all cells analyzed. Because these results are not quantitative, they cannot exclude innervation-dependent quantitative differences in NR2A mRNA levels. Thus, the conclusion that can be drawn is limited to the point that NR2A mRNA is expressed in dg-innervated and noninnervated neurons. This additionally supports the expression of ternary NMDA receptors in these neurons.

\section{Delayed developmental maturation of synaptic NMDA receptors in dg-innervated neurons}

During development of the hippocampus in vivo, fast decaying NMDA EPSC components consistent with the expression of NR1/ NR2A receptors appear during developmental maturation of glutamatergic synapses (Khazipov et al., 1995). After 1 week in 
culture a minority of dg-innervated neurons showed fast decaying NMDA EPSC components, suggesting that the developmental maturation of synaptic NMDA receptors might be delayed in dg-innervated neurons because of a lack of presynaptic signals. To examine this, we recorded mEPSCs in dg-innervated neurons after prolonged cultivation. After 11-12 d in vitro a fast decaying NMDA receptor-mediated component $(\tau=77 \pm 23 \mathrm{msec},>60 \%$ of total amplitude) was found in two thirds of dg-innervated neurons $(n=12)$. Thus, the innervation-dependent difference in the functional expression of NR1/NR2A receptors seemed to be caused by a delayed developmental maturation of glutamatergic synapses in neurons innervated by dg explants.

\section{DISCUSSION}

We have developed and characterized a co-culture system that has enabled us to control the innervation of postsynaptic target neurons obtained from the CA region of the embryonic rat hippocampus. Explants from different, defined hippocampal regions were used as sources of innervation. In our co-cultures, glutamatergic synaptic input to target neurons arose from outgrowing explant fibers, as demonstrated by the absence of synapses between target neurons and by the absence of autapses. The formation of glutamatergic synapses by different types of explants, i.e., from the $\mathrm{dg}$ and the CA region, was comparable, as indicated by quantitatively similar frequencies and amplitudes of AMPA mEPSCs. Different types of explants might selectively establish synapses on specific subsets of target neurons and/or selectively form synapses on specific subcellular regions of target neurons. Both types of explants, however, established glutamatergic synapses on almost all target neurons surrounding an explant and on both proximal and distal dendritic regions of target neurons, thus excluding selective synapse formation.

\section{Presynaptic control of NMDA receptor subtypes}

Studies of NMDA receptor subtypes in heterologous expression systems have established that the kinetic and pharmacological properties of NMDA receptors are determined by their subunit composition (Kutsuwada et al., 1992; Monyer et al., 1992, 1994; Williams et al., 1993; Williams, 1995; Köhr and Seeburg, 1996). Here, we used kinetic and pharmacological properties of NMDA EPSCs and of NMDA receptor-mediated currents to analyze differences in the subunit composition of NMDA receptors in target neurons. With both types of innervation, postsynaptic NMDA receptors were strongly sensitive to $\mathrm{Mg}^{2+}$ blockade, indicating that they contained NR2A or NR2B subunits or both.

The kinetic properties of NMDA receptor-mediated currents are characteristic of distinct subunit compositions of NMDA receptor subtypes containing NR2A or NR2B subunits or both. Binary NR1/NR2A receptors show fast offset kinetics, whereas NR1/NR2B receptors are indicated by slow offset kinetics (Monyer et al., 1992, 1994). Ternary NR1/NR2A/NR2B receptors are characterized by intermediate offset kinetics (Köhr and Seeburg, 1996). Because offset kinetics of NMDA receptors determine the decay kinetics of NMDA EPSCs (Hestrin et al., 1990; Lester et al., 1990), the analysis of NMDA EPSC kinetics allows the differences in subunit composition of NMDA receptors to be studied. In addition, we studied the offset kinetics of NMDA receptor-mediated currents that were elicited by L-glutamate application. After 1 week in culture in target neurons innervated by $\mathrm{dg}$ explants, the kinetic analysis of NMDA receptors indicated the subunit composition NR1/NR2A/NR2B or NR1/NR2B or both. In target neurons innervated by $\mathrm{CA}$ explants, strikingly different, fast kinetics of NMDA receptors were found, indicating the additional expression of NR1/NR2A receptors. Because NMDA receptor kinetics in noninnervated neurons were similar to that of dg-innervated neurons, this innervation-dependent difference in the expression of NR1/NR2A receptors suggests that they were induced selectively in neurons innervated by CA explants. The innervation-dependent difference in the expression of NMDA receptor subtypes was transient because of a delayed developmental maturation of NMDA receptors in neurons innervated by $\mathrm{dg}$ explants. Thus, CA explants seem to generate more efficiently the presynaptic signals that control the expression of NR1/NR2A receptors. The selective expression of NR1/NR2A receptors was confirmed pharmacologically. After 1 week in culture, NMDA receptors were blocked only partially by the well established NR2B subunit selective antagonist ifenprodil in CA-innervated neurons. In contrast, ifenprodil blocked NMDA receptors almost completely in dg-innervated neurons. To this end, our results demonstrate that the subunit composition of synaptic NMDA receptors is determined by presynaptic signaling.

In dg-innervated neurons, which were cultured for 7-9 d, and in noninnervated neurons, the expression of ternary NR1/NR2A/ NR2B receptors was indicated by intermediate offset kinetics. Although direct comparison of the kinetics of dendritic currents with data obtained from outside-out patches is not possible because of the kinetic limitations of whole dendrite application, our results in neurons innervated by dg explants agree with offset kinetics in outsideout patches from the mossy fiber termination zone of CA3 pyramidal neurons (Spruston et al., 1995). In addition to kinetic properties, the expression of NR1/NR2A/NR2B receptors was suggested by the expression of NR2A mRNA in dg-innervated and noninnervated neurons. In vivo, the expression of ternary receptors has been demonstrated in the visual cortex on the basis of immunoprecipitation experiments (Sheng et al., 1994).

The functional expression of synaptic NR1/NR2A receptor complexes may represent a major postsynaptic step in the development of mature properties of central glutamatergic synapses. This is supported by developmental changes in the kinetic properties of NMDA EPSCs in vivo (Carmignoto and Vicini, 1992; Hestrin, 1992; Khazipov et al., 1995). These changes are accompanied by a developmental increase in the expression of NR2A subunits (Watanabe et al., 1992; Monyer et al., 1994, Sheng et al., 1994). Our study indicates the control of NR1/NR2A receptor expression by presynaptic signaling. The molecular mechanisms that are involved remain to be studied. Activity-dependent mechanisms might contribute to presynaptic control of NMDA receptor subunit composition. This idea is supported by inhibitory effects of electrical activity blockade on the developmental appearance of fast decaying NMDA EPSC components (Carmignoto and Vicini, 1992) and on NR2A mRNA expression (Audinat et al., 1994; Bessho et al., 1994).

Our findings have important implications for the mechanisms underlying differences in long-term plasticity of glutamatergic synapses. First, in hippocampal CA3 pyramidal neurons, longterm potentiation at different, anatomically distinct synaptic inputs is either NMDA receptor-dependent or NMDA receptorindependent (Zalutsky and Nicoll, 1990). Presynaptic control of subsynaptic NMDA receptor expression might be a mechanism that contributes to synapse-specific differences in long-term plasticity. Second, drastic changes in the susceptibility to long-term potentiation occur during development of the visual cortex and the hippocampal formation (Crair and Malenka, 1995; Izumi and Zorumski, 1995). Differences in subunit composition of NMDA 
receptors seem to underlie these developmental maturation processes (Carmignoto and Vicini, 1992; Watanabe et al., 1992; Williams et al., 1993; Monyer et al., 1994; Sheng et al., 1994,; Khazipov et al., 1995). Thus, signals from presynaptic neurons may play a major role in regulating long-term plasticity of central glutamatergic synapses by controlling NMDA receptor subunit composition.

\section{REFERENCES}

Ascher P, Nowak L (1988) The role of divalent cations in the $N$-methylD-aspartate responses of mouse central neurones in culture. J Physiol (Lond) 399:247-266.

Audinat E, Lambolez B, Rossier J, Crépel F (1994) Activity-dependent regulation of $N$-methyl-D-aspartate receptor subunit expression in rat cerebellar granule cells. Eur J Neurosci 6:1792-1800.

Bekkers JM, Stevens CF (1989) NMDA and non-NMDA receptors are colocalized at individual excitatory synapses in cultured rat hippocampus. Nature 341:230-233.

Bekkers JM, Stevens CF (1991) Excitatory and inhibitory autaptic currents in isolated hippocampal neurons maintained in cell culture. Proc Natl Acad Sci USA 88:7834-7838.

Benke TA, Jones OT, Collingridge GL, Angelides KJ (1993) N-methylD-aspartate receptors are clustered and immobilized on dendrites of living cortical neurons. Proc Natl Acad Sci USA 90:7819-7823.

Bessho Y, Nawa H, Nakanishi S (1994) Selective up-regulation of an NMDA receptor subunit mRNA in cultured cerebellar granule cells by $\mathrm{K}^{+}$-induced depolarization and NMDA treatment. Neuron 12:87-95.

Bliss TVP, Collingridge GL (1993) A synaptic model of memory: longterm potentiation in the hippocampus. Nature 361:31-39.

Carmignoto G, Vicini S (1992) Activity-dependent decrease in NMDA receptor responses during development of the visual cortex. Science 258:1007-1011.

Church J, Fletcher EJ, Baxter K, MacDonald JF (1994) Blockade by ifenprodil of high voltage-activated $\mathrm{Ca}^{2+}$ channels in rat and mouse cultured hippocampal neurones: comparison with $N$-methyl-D-aspartate receptor antagonist actions. Br J Pharmacol 113:499-507.

Collingridge GL, Singer W (1990) Excitatory amino acid receptors and synaptic plasticity. Trends Pharmacol Sci 11:290-296.

Crair MC, Malenka RC (1995) A critical period for long-term potentiation at thalamocortical synapses. Nature 375:325-328.

Gottmann K, Pfrieger FW, Lux HD (1994) The formation of glutamatergic synapses in cultured central neurons: selective increase in miniature synaptic currents. Dev Brain Res 81:77-88.

Hall ZW, Sanes JR (1993) Synaptic structure and development: the neuromuscular junction. Cell [Suppl] 72:99-121.

Hestrin S (1992) Developmental regulation of NMDA receptormediated synaptic currents at a central synapse. Nature 357:686-689.

Hestrin S, Sah P, Nicoll RA (1990) Mechanisms generating the time course of dual component excitatory synaptic currents recorded in hippocampal slices. Neuron 5:247-253.

Hollmann M, Heinemann S (1994) Cloned glutamate receptors. Annu Rev Neurosci 17:31-108.

Izumi Y, Zorumski CF (1995) Developmental changes in long-term potentiation in CA1 of rat hippocampal slices. Synapse 20:19-23.

Khazipov R, Ragozzino D, Bregestovski P (1995) Kinetics and $\mathrm{Mg}^{2+}$ block of $N$-methyl-D-aspartate receptor channels during postnatal development of hippocampal CA3 pyramidal neurons. Neuroscience 69:1057-1065.

Köhr G, Seeburg PH (1996) Subtype-specific regulation of recombinant NMDA receptor-channels by protein tyrosine kinases of the src family. J Physiol (Lond) 492:445-452.

Kutsuwada T, Kashiwabuchi N, Mori H, Sakimura K, Kushiya E, Araki K, Meguro H, Masaki H, Kumanishi T, Arakawa M, Mishina M (1992) Molecular diversity of the NMDA receptor channel. Nature 358:36-41.

Lambolez B, Audinat E, Bochet P, Crepel F, Rossier J (1992) AMPA receptor subunits expressed by single Purkinje cells. Neuron 9:247-258.

Lester RAJ, Clements JD, Westbrook GL, Jahr CE (1990) Channel kinetics determine the time course of NMDA receptor-mediated synaptic currents. Nature 346:565-567.
MacDermott AB, Mayer ML, Westbrook GL, Smith SJ, Barker JL (1986) NMDA-receptor activation increases cytoplasmic calcium concentration in cultured spinal cord neurones. Nature 321:519-522.

Mayer ML, Westbrook GL, Guthrie PB (1984) Voltage-dependent block by $\mathrm{Mg}^{2+}$ of NMDA responses in spinal cord neurones. Nature 309:261-263.

Meguro H, Mori H, Araki K, Kushiya E, Kutsuwada T, Yamazaki M, Kumanishi T, Arakawa M, Sakimura K, Mishina M (1992) Functional characterization of a heteromeric NMDA receptor channel expressed from cloned cDNAs. Nature 357:70-74.

McBain CJ, Mayer ML (1994) $N$-methyl-D-aspartic acid receptor structure and function. Physiol Rev 74:723-760.

Monaghan DT, Cotman CW (1985) Distribution of $N$-methyl-Daspartate-sensitive L- $\left[{ }^{3} \mathrm{H}\right]$ glutamate-binding sites in rat brain. J Neurosci 5:2909-2919.

Monyer H, Sprengel R, Schoepfer R, Herb A, Higuchi M, Lomeli H, Burnashev N, Sakmann B, Seeburg PH (1992) Heteromeric NMDA receptors: molecular and functional distinction of subtypes. Science 256:1217-1221.

Monyer H, Burnashev N, Laurie DJ, Sakmann B, Seeburg PH (1994) Developmental and regional expression in the rat brain and functional properties of four NMDA receptors. Neuron 12:529-540.

Moriyoshi K, Masu M, Ishii T, Shigemoto R, Mizuno N, Nakanishi S (1991) Molecular cloning and characterization of the rat NMDA receptor. Nature 354:31-37.

Nowak L, Bregestovski P, Ascher P, Herbert A, Prochiantz A (1984) Magnesium gates glutamate-activated channels in mouse central neurones. Nature 307:462-465.

Petralia RS, Yokotani N, Wenthold RJ (1994) Light and electron microscope distribution of the NMDA receptor subunit NMDAR1 in the rat nervous system using a selective anti-peptide antibody. J Neurosci 14:667-696.

Pfrieger FW, Veselovsky NS, Gottmann K, Lux HD (1992) Pharmacological characterization of calcium currents and synaptic transmission between thalamic neurons in vitro. J Neurosci 12:4347-4357.

Pfrieger FW, Gottmann K, Lux HD (1994) Kinetics of GABA B $_{\mathrm{B}}$ receptormediated inhibition of calcium currents and excitatory synaptic transmission in hippocampal neurons in vitro. Neuron 12:97-107.

Sakimura K, Kutsuwada T, Ito I, Manabe T, Takayama C, Kushiya E, Yagi T, Aizawa S, Inoue Y, Sugiyama H, Mishina M (1995) Reduced hippocampal LTP and spatial learning in mice lacking NMDA receptor $\epsilon 1$ subunit. Nature 373:151-155.

Schneggenburger R, Zhou Z, Konnerth A, Neher E (1993) Fractional contribution of calcium to the cation current through glutamate receptor channels. Neuron 11:133-143.

Sheng M, Cummings J, Roldan LA, Jan YN, Jan LY (1994) Changing subunit composition of heteromeric NMDA receptors during development of rat cortex. Nature 368:144-147.

Siegel SJ, Brose N, Janssen WG, Gasic GP, Jahn R, Heinemann SF, Morrison JH (1994) Regional, cellular, and ultrastructural distribution of $N$-methyl-D-aspartate receptor subunit 1 in monkey hippocampus. Proc Natl Acad Sci USA 91:564-568.

Spruston N, Jonas P, Sakmann B (1995) Dendritic glutamate receptor channels in rat hippocampal CA3 and CA1 pyramidal neurons. J Physiol (Lond) 482:325-352.

Watanabe M, Inoue Y, Sakimura K, Mishina M (1992) Developmental changes in distribution of NMDA receptor channel subunit mRNAs. NeuroReport 3:1138-1140.

Weisskopf MG, Nicoll RA (1995) Presynaptic changes during mossy fibre LTP revealed by NMDA receptor-mediated synaptic responses. Nature 376:256-259.

Williams K (1995) Pharmacological properties of recombinant $N$-methyl$\mathrm{D}$-aspartate (NMDA) receptors containing the $\epsilon 4$ (NR2D) subunit. Neurosci Lett 184:181-184.

Williams K, Russel SL, Shen YM, Mollinoff PB (1993) Developmental switch in the expression of NMDA receptors occurs in vivo and in vitro. Neuron 10:267-278.

Zalutsky RA, Nicoll RA (1990) Comparison of two forms of long-term potentiation in single hippocampal neurons. Science 248:1619-1624. 